\author{
RYSZARD MAZUREK*, JOANNA BEATA KOWALSKA, PAWEŁ ZADROŻNY, \\ MICHAŁ GAZSIOREK, HALINA KOZAK
}

University of Agriculture, Department of Soil Science and Soil Protection

Al. Mickiewicza 21, 31-120 Kraków, Poland

\title{
Rendzinas diversity of the Ojców National Park as an effect of lithological factors
}

\begin{abstract}
The aim of this study was to investigate rendzinas diversity on the area of the Ojców National Park (ONP), southern Poland. Moreover, the paper aims to identify the relation between relief and soil cover slope position and its influence on classification as well as the occurrence of lithological discontinuity. The studied soils were classified as brown and chernozemic rendzinas. Rendzinas in the area of the ONP are located mainly in the middle slope position where Upper Jurassic limestones regolith is mixed with loess sediments. This situation leads to vertical heterogeneity of soil texture (and formation of rendzinas with lithological discontinuity) within the soil profile. Surface horizons were mainly characterized by silty texture while in deeper horizons there was a more clay-like texture, which was the result of weathering Jurassic limestones located in deeper parts of soil profile. In turn, uniform shallow rendzinas occurred only on exposed rocks composed of limestones, where loess cover was absent. The character of ONP's soils is also the result of parent material heterogeneity conditioned by long-term changes e.g. denudation processes and/or weathering. In order to assess soil heterogeneity, 'lithological discontinuity indices' as well as 'uniformity values' have been applied.
\end{abstract}

Keywords: rendzina, calcareous soils, the Ojców National Park, lithological discontinuity

\section{INTRODUCTION}

The Ojców National Park (ONP) is the smallest in Poland and located along the Prądnik and Sąspówka river valleys cutting deep into Upper Jurassic (Oxfordian) limestones. One of the most important components of soil cover in the area of the Ojców National Park are humus-calcareous soils classified as rendzinas (Mazurek et al. 2010, Mazurek and Zadrożny 2011). Occurrence of rendzinas is an obvious element of characteristic landscape of the Praqnik Valley, conditioned by presence of Jurassic limestones. Rendzinas were already reported in the first soil map of the ONP prepared by Greszta and Bitka (1977) as well as in later research by Zalewa (2001). A lot of studies concerning the ONP's rendzinas were devoted to the pollution of this soil type by heavy metals (SchejbalChwastek and Marszałek 1999, Mazurek et al. 2010, Mazurek and Zadrożny 2011) and sulphur (Mazurek and Zadrożny 2013).

Rendzinas were the subject of many studies not only from the ONP but also from other parts of Poland. Often such papers deal with chemical and physical properties (Ciarkowska 2000, Ciarkowska and Niemyska-Łukaszuk 2004, Miechówka 2001, 2002) mineralogy (Dobrzański and Turski 1964, Za-

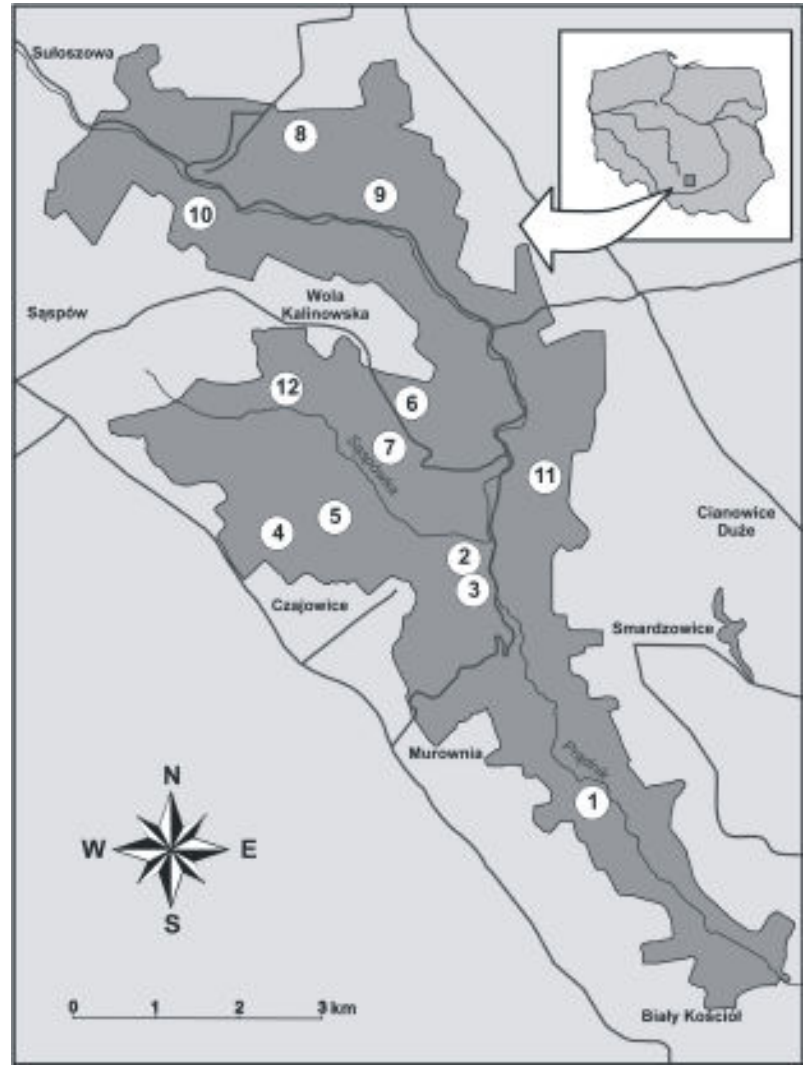

FIGURE 1. Location of study area and soil profiles 
górski 2001, Kowalska et al. 2017) as well as micromorphology (Ciarkowska and Niemyska-Łukaszuk 2004, Kowaliński and Licznar 1976, Licznar 1976, Zagórski 2001). Furthermore, many studies concerning rendzinas were focused on organic matter decomposition (Kuźnicki and Skłodowski 1973, Kowaliński and Licznar 1976, Pranagal 2004). The influence of various parent materials on soil development has been assessed within Polish rendzinas (Strzemski 1950, Kuźnicki 1965, Kuźnicki and Skłodowski 1976, Zasoński 1992, Zagórski 2001).

However, until now there is a lack of detailed studies concerning the genesis and evolution of rendzinas particularly at the area of the ONP. Furthermore, so far there was no comprehensive research related to the heterogeneity of such soils based mostly on their texture as in this case. This subject needs a detailed insight into the properties and development of this soil type.

It has to be mentioned that some studies assumed soil heterogeneity is unusual for soil environment (Ahr et al. 2012, Schaetzl and Anderson 2005). Lorz et al. (2013) discuss the idea of soil evolution based on downward formation from top to down part of soil profile characteristic of homogenous soil substrate. Nevertheless, soil evolution could be more complex and marked by differences between two horizons or layers in soil profile (Ligęza 2009, Lorz and Phillips 2006, Lorz et al. 2010, Kowalska et al. 2016, Waroszewski et al. 2013, 2015, 2017a, 2017b). Heterogenic soils have a complicated but widely discussed genesis (Schaetzl and Anderson 2005, Waroszewski et al. 2015, 2017b). Polygenetic soil development often includes mass movement, soil reworking and erosion as well as aeolian admixture (Kowalska et al. 2016, Schaetzl and Anderson 2005, Waroszewski et al. 2013).

Regarding the above-mentioned, we examined the rendzinas diversity in the ONP area. Moreover, the paper aims to identify the relation between relief and slope position of rendzinas occurrence and its influence on soil classification as well as any presence of lithological discontinuity. Additionally, we aimed to show the vertical heterogeneity profile of ONP soils as an effect of lithological variability.

\section{STUDY AREA}

The study was conducted throughout the ONP (Fig. 1). The ONP is an upland limestone area covered with loess sediments. The geomorphology of the study area is characteristic with deep central valleys cut out by Prądnik and Saspówka rivers surrounded by steep slopes sometimes with the character of rocky cliffs. Contemporary soil cover is the result of long and complex changes reflecting the periods of relief planation, development of the underground karst and filling with glacial and aeolian sediments as well as periods in which old forms were covered by the younger sediments (Fig. 2). Soil cover is mostly conditioned by differentiation of parent material (Greszta and Bitka 1977, Zalewa 2001). The deepest layers consist of rocky and shallow Upper Jurassic limestone at up to $100 \mathrm{~m}$ thick. These layers are covered by younger Quaternary sediments, primarily by loess and Pleistocene clays. Valleys bases are filled by the youngest sediments in the form of alluvium and deluvium. Furthermore, clay-illuvial soils may be formed on deep loess sediments. In the valleys and tectonic sinkholes, swamp and peat soils often occur. Finally, along the rivers, alluvial soils formed from river sediments composed of sands and silts (Greszta and Bitka 1977, Zalewa 2001) (Fig. 2).

\section{MATERIALS AND METHODS}

Our soil samples have been collected from 12 rendzinas profiles located in the forested areas of the ONP (Figs 1 and 3). In the study area, Dentario glandulosae-Fagetum occurs as the dominant plant com-

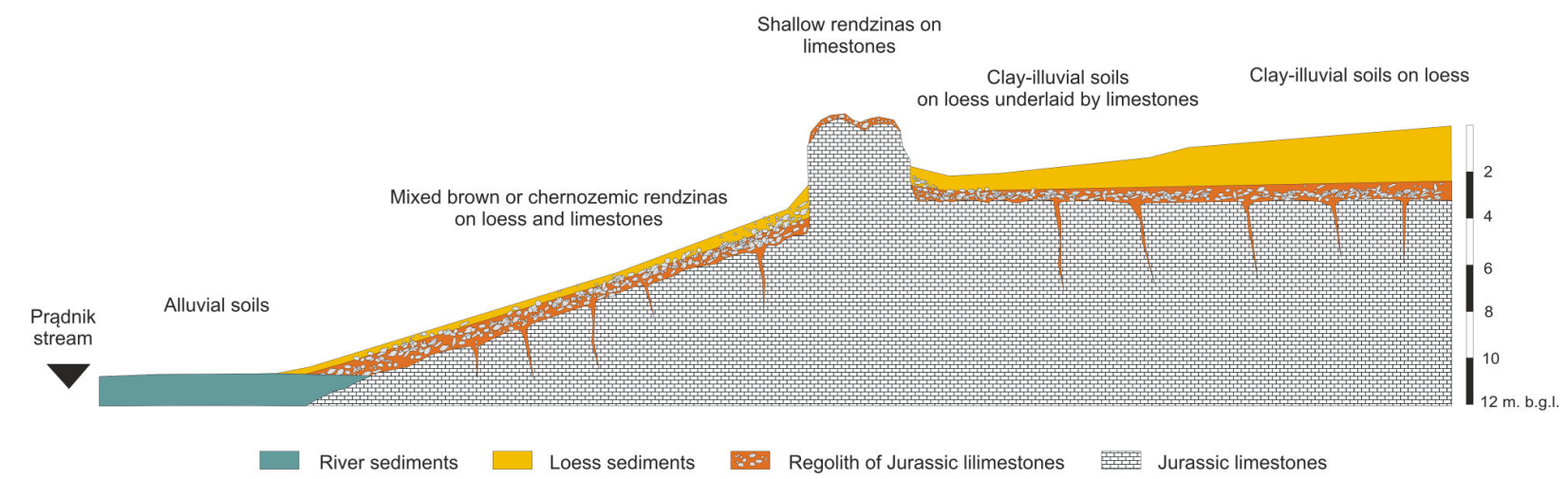

FIGURE 2. Schematic soil catena showing parent material and soil unit diversification regarding slope position in the Ojców National Park 

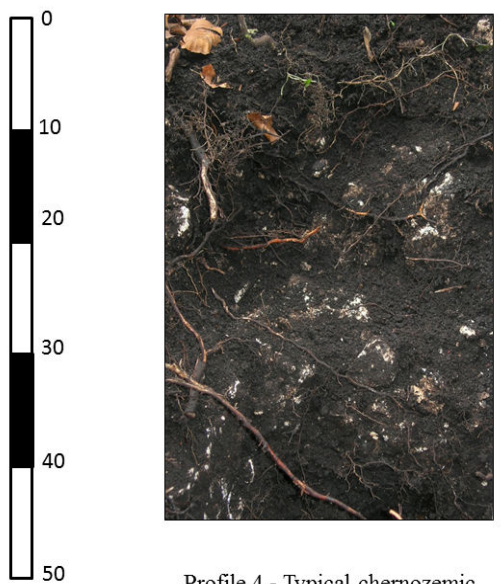

Profile 4 - Typical chernozemic rendzina (mixed) Rendzic Hyperskeletic Leptosol (Hyperhumic, Loamic)
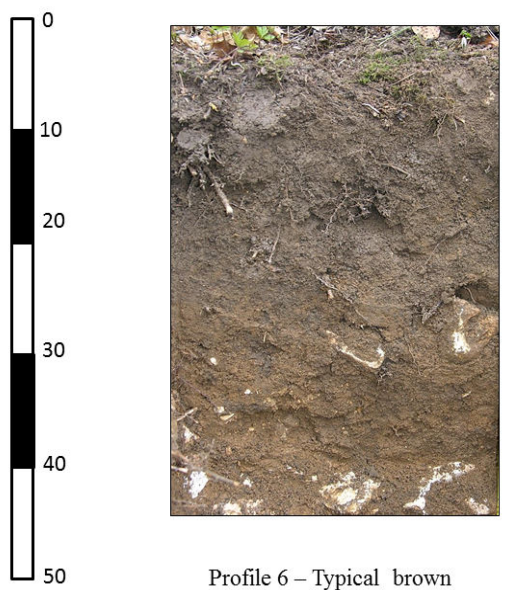

Profile 6 - Typical brown rendzina (mixed) Eutric Calcaric Epileptic Cambisol (Humic, Epiraptic, Siltic)

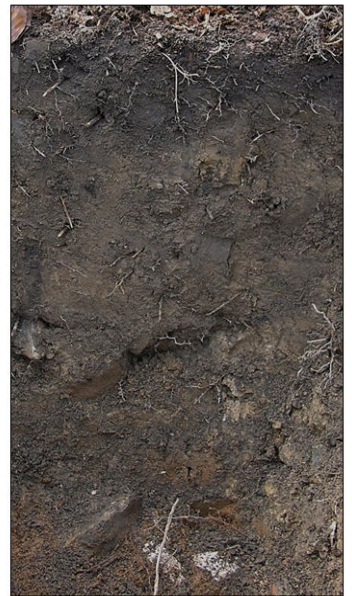

Profile 11 - Brown chernozemic rendzina Skeletic Cambic Endoleptic Rendzic Phaeozem (Siltic)

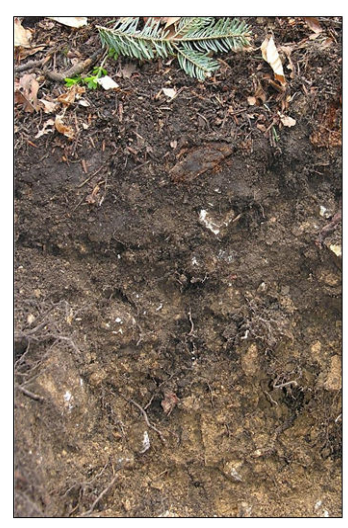

Profile 10 - Typical brown rendzina (mixed) Eutric Calcaric Epileptic Cambisol (Humic, Epiraptic, Siltic)

FIGURE 3. Profiles of studied rendzinas

munity (Medwecka-Kornaś and Kornaś 1963). The morphology of soils was described based on FAO (2006) system (Table 1). The colour of each separated horizon was determined based on the "Revised Standard Soil Color Charts" (Oyama and Takehara 1970). Soil samples were collected from all distinguished genetic horizons for further physico-chemical analyses. The samples were air dried and sieved through a certified plastic sieve ( $2 \mathrm{~mm}$ diameter mesh). The soil texture of studied soils was determined using the Bouyoucos aerometric method (without carbonates removal), modified by Cassagrande and Prószyński (Polish Standard 1998). According to the norm, in the fine earth parts $(<2 \mathrm{~mm})$ the percentage of the silt and clay fraction was determined by the areometric method, and the percentage of individual sand sub-fractions was determined by the sieve method. Potentiometric measurements of $\mathrm{pH}$ were taken using a standard combination electrode and CPI-551 Elmetron $\mathrm{pH}$ meter in suspension of $\mathrm{H}_{2} \mathrm{O}$ and $1 \mathrm{~mol} \cdot \mathrm{dm}^{-3} \mathrm{KCl}$, in a ratio of $1: 2.5(\mathrm{w} / \mathrm{v})$. The content of total organic carbon (TOC) was determined using the Tiurin method (Lityński et al. 1976). The content of total nitrogen $\left(\mathrm{N}_{\text {tot }}\right)$ was determined using the Kjeldahl method (Lityński et al. 1976) on a FOSS Kjeltec TM 8100 apparatus. Calcium carbonate content was determined using the Scheibler method (Lityński et al. 1976).

A lithological discontinuity (LD) detection could be determined on the base of soil texture (Lorz and Phillips 2006, Lorz 2008, Ligęza 2009, Waroszewski et al. 2015). Based on the formulas given by Kowalska et al. (2016) three different methods to identify the presence of LD in the soils were used. Lithological discontinuity indices (LDI) have been calculated for each studied soil profile.

Similarly, Uniformity Value indices (UV1 and UV2) were calculated in order to evaluate heterogenity of soil profiles (Kowalska et al. 2016, Schaetzl and Anderson 2005).

Soils have been classified based on both Polish Soil Classification (2011) (please see the Discussion chapter) and World Reference Base for Soil Resources (WRB) (IUSS Working Group 2015) (Table 2).

\section{RESULTS}

All studied soil profiles were described in the field. The studied profile characteristic traits were low content of coarse (skeletic) fraction in humus horizons. The horizontal arrangement of the skeleton was high in the $\mathrm{AC}$ and/or $\mathrm{BC}$ horizons and gradually decreased towards to the topsoil (Table 1). The boundaries between the horizons were mostly diffuse and clear. In general, the medium and coarse size classes of structure were found. In terms of the type of macrostructure, the analyzed soils were characterized by single crumbs in humus horizons, and in deeper partition of soil profiles subangular structure occurred. The structure development of soil aggregates was moderate. Upper horizons were characterized by firm and friable consistency, while lower horizons were mostly firm or very firm. The studied horizons were mostly moist but also slightly moist (profiles 7 and 11), very moist (profile 2) and wet (profile 8). The frequency of the presence of roots in upper horizon ranged from common to few. In deeper soil profile parts ranged from few to none (Table 1). 
TABLE 1. Field soil characteristics (FAO 2006)

\begin{tabular}{|c|c|c|c|c|c|c|c|c|c|}
\hline $\begin{array}{l}\text { Profile } \\
\text { No. }\end{array}$ & Horizon & $\begin{array}{l}\text { Depth } \\
(\mathrm{cm})\end{array}$ & Colour & Boundary & Structure & $\begin{array}{l}\begin{array}{l}\text { Consistence } \\
\text { (moist) }\end{array} \\
\end{array}$ & $\begin{array}{l}\text { Rock } \\
\text { fragment (\%) }\end{array}$ & Moisture & $\begin{array}{l}\text { Abundance } \\
\text { of roots }\end{array}$ \\
\hline \multirow[t]{5}{*}{1} & Oi & $2-0$ & - & - & - & - & - & - & - \\
\hline & Ah1 & $0-2$ & 10YR 3/5 & $\mathrm{D}$ & ME MO CR & FR & 0 & $\mathrm{VM}$ & $\mathrm{C}$ \\
\hline & Ah2 & $2-23$ & $10 Y R 3 / 4$ & $\mathrm{D}$ & ME MO CR & FR & 10 & $\mathrm{M}$ & $\mathrm{F}$ \\
\hline & BCcal & $23-56$ & $10 Y R 4 / 4$ & $\mathrm{C}$ & ME MO CR & FI & 50 & $\mathrm{M}$ & $\mathrm{F}$ \\
\hline & BCca2 & 56-78 & $10 Y R$ 4/6 & - & ME MO CR & FI & 80 & $\mathrm{M}$ & $\mathrm{F}$ \\
\hline \multirow[t]{3}{*}{2} & Oi & $1-0$ & - & - & - & - & - & - & - \\
\hline & $\mathrm{A}$ & $0-7$ & 10YR 3/3 & $\mathrm{C}$ & ME MO CR & FR & - & $\mathrm{VM}$ & $\mathrm{M}$ \\
\hline & $\mathrm{BCca}$ & $7-29$ & $10 \mathrm{YR} 4 / 6$ & - & ME MO CR & FI & 85 & $\mathrm{VM}$ & $\mathrm{F}$ \\
\hline \multirow[t]{4}{*}{3} & Oi & $2-0$ & - & - & - & - & - & - & - \\
\hline & $\mathrm{A}$ & $0-13$ & 10YR 2/1 & $\mathrm{D}$ & ME ST CR & FI & 40 & $\mathrm{M}$ & $\mathrm{C}$ \\
\hline & Aca & $13-23$ & 10YR 3/4 & $\mathrm{D}$ & CO MO CR & FI & 60 & $\mathrm{M}$ & $\mathrm{C}$ \\
\hline & $\mathrm{Cca}$ & $23-43$ & 10YR 5/6 & - & CO MO CR & FR & 80 & $M$ & $\mathrm{~F}$ \\
\hline \multirow[t]{3}{*}{4} & Oi & $2-0$ & - & - & - & - & - & - & - \\
\hline & OCca1 & $0-8$ & 10YR 4/6 & $\mathrm{D}$ & ME MO CR & FR & 30 & $\mathrm{M}$ & $\mathrm{M}$ \\
\hline & ACca2 & $8-43$ & 10YR 2/1 & - & ME MO CR & $\mathrm{FR}$ & 90 & $\mathrm{M}$ & $\mathrm{F}$ \\
\hline \multirow[t]{3}{*}{5} & Oi & $2-0$ & - & - & - & - & - & - & - \\
\hline & ACca1 & $0-6$ & 10YR 2/1 & $\mathrm{C}$ & ME MO CR & FR & 30 & $\mathrm{M}$ & $\mathrm{C}$ \\
\hline & ACca2 & $6-33$ & 10YR 2/1 & - & ME MO CR & FR & 60 & $\mathrm{M}$ & $\mathrm{F}$ \\
\hline \multirow[t]{3}{*}{6} & Oi & $1-0$ & - & - & - & - & - & - & - \\
\hline & $\mathrm{Ah}$ & $0-18$ & $10 Y R 3 / 3$ & $\mathrm{D}$ & ME ST CR & FR & 10 & $\mathrm{M}$ & $\mathrm{C}$ \\
\hline & $\overline{\mathrm{AB}}$ & $18-40$ & 10YR 4/6 & - & CO WE SB & FI & 50 & $\mathrm{M}$ & $\mathrm{F}$ \\
\hline \multirow[t]{4}{*}{7} & $\mathrm{Oi}$ & $2-1$ & - & - & - & - & - & - & - \\
\hline & $\mathrm{Oa}$ & $1-0$ & - . & $\mathrm{D}$ & - & - & - & SM & $\mathrm{F}$ \\
\hline & ACca & $0-26$ & 10YR 2/1 & $\mathrm{D}$ & ME MO CR & FR & 75 & SM & $\mathrm{F}$ \\
\hline & BCca & $26-38$ & $10 \mathrm{YR} 4 / 3$ & - & $\mathrm{CO} \mathrm{MO} \mathrm{CR}$ & FI & 90 & SM & $\mathrm{N}$ \\
\hline \multirow[t]{4}{*}{8} & Oi & $3-2$ & - & - & - & - & - & - & - \\
\hline & Oia & $2-0$ & - & $\mathrm{C}$ & - & - & - & $\mathrm{W}$ & $\mathrm{C}$ \\
\hline & ACca & $0-17$ & 10YR 3/1 & $\mathrm{C}$ & ME MO CR & FR & 30 & $\mathrm{~W}$ & $\mathrm{C}$ \\
\hline & $\mathrm{BCca}$ & $25-45$ & $10 \mathrm{YR} 4 / 6$ & - & ME MO CR & FI & 85 & $\mathrm{~W}$ & $\mathrm{~F}$ \\
\hline \multirow[t]{4}{*}{9} & Oia & $2-0$ & - & - & - & - & - & - & - \\
\hline & $\mathrm{Ah}$ & $0-14$ & 10YR 3/3 & $\mathrm{C}$ & ME ST CR & FR & 0 & $\mathrm{M}$ & $\mathrm{M}$ \\
\hline & $\mathrm{AhB}$ & $14-31$ & 10YR 4/4 & $\mathrm{C}$ & CO MO SB & FI & 0 & $\mathrm{M}$ & $\mathrm{C}$ \\
\hline & $2 \mathrm{C}$ & $31-53$ & 7.5 YR 5/8 & - & CO MO SB & VFI & 70 & $\mathrm{M}$ & $\mathrm{F}$ \\
\hline \multirow[t]{3}{*}{10} & Oia & $1-0$ & - & - & - & - & - & - & - \\
\hline & $\mathrm{Ah}$ & $0-15$ & $10 \mathrm{YR} 2 / 2$ & $\mathrm{D}$ & ME ST CR & FR & - & $\mathrm{M}$ & $\mathrm{C}$ \\
\hline & BCca & $15-37$ & $10 \mathrm{YR} 2 / 2$ & - & $\mathrm{CO} \mathrm{MO} \mathrm{SB}$ & FI & 60 & $\mathrm{M}$ & $\mathrm{C}$ \\
\hline \multirow[t]{4}{*}{11} & $\mathrm{Oi}$ & $1-0$ & - & - & - & - & - & - & - \\
\hline & ACcal & $0-11$ & $10 Y R 2 / 3$ & $\mathrm{C}$ & ME MO CR & FR & - & SM & $\mathrm{C}$ \\
\hline & ACca2 & $11-29$ & $10 Y R 3 / 3$ & $\mathrm{C}$ & ME MO CR & FI & 30 & SM & $\mathrm{F}$ \\
\hline & BCca & $29-59$ & $10 \mathrm{YR} 4 / 6$ & - & CO WE SB & VFI & 90 & SM & $\mathrm{V}$ \\
\hline \multirow[t]{4}{*}{12} & Oi & $1-0$ & - & - & - & - & - & - & - \\
\hline & $\mathrm{A}$ & $0-13$ & 10YR $2 / 3$ & $\mathrm{D}$ & ME MO CR & FR & 10 & $\mathrm{M}$ & $\mathrm{C}$ \\
\hline & ACca & $13-24$ & 10YR $3 / 3$ & $\mathrm{C}$ & ME MO CR & FI & 90 & $\mathrm{M}$ & $\mathrm{F}$ \\
\hline & $\mathrm{BCca}$ & $24-39$ & $10 Y R 4 / 4$ & - & CO WE SB & VFI & 90 & $\mathrm{M}$ & $\mathrm{V}$ \\
\hline
\end{tabular}

Explanations: - not determined.

(O horizon): Structure: 1) Size classes: VF - very fine; ME - medium; CO - coarse. 2) Types of structure: SB - subangular blocky;

$\mathrm{CR}$ - crumby. 3) Classification of structure: WE - weak; MO - moderate; ST - strong.

Boundary: A - abrupt; C - clear; G - gradual; D - diffuse.

Abundance of roots (FAO, 2006): N - none; v - very few; F - few; C - common; M - many. Moisture: SM - slightly moist; M - moist;

W - wet; VW - very wet.

Consistence: FR - friable, FI - firm, VFI - very firm. 


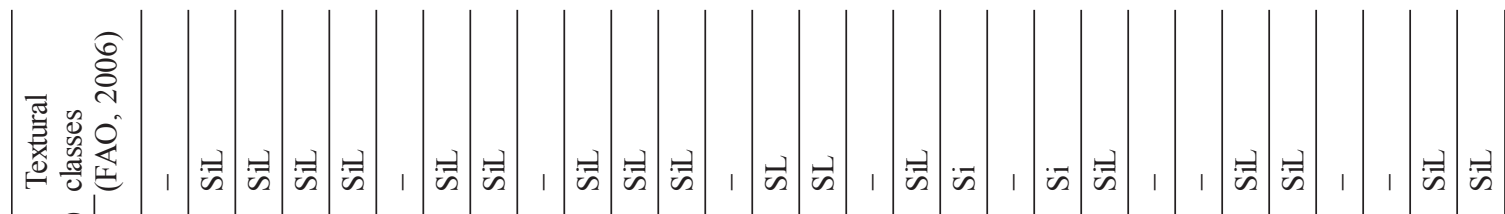

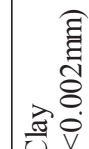

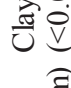

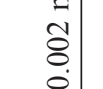

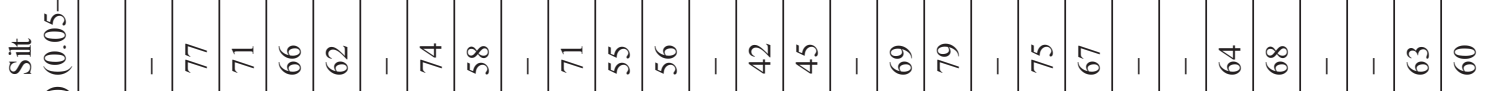
สิ

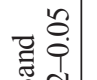
I)$$
8^{m} T_{60} \quad 0 . m 000
$$$$
\text { 胥 }
$$

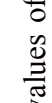

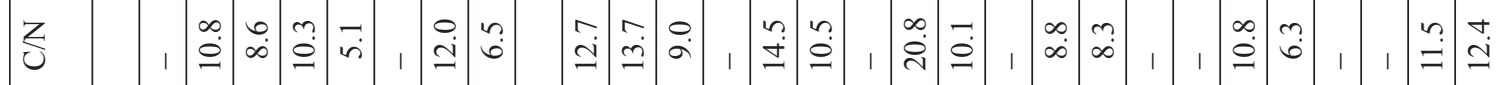

穴

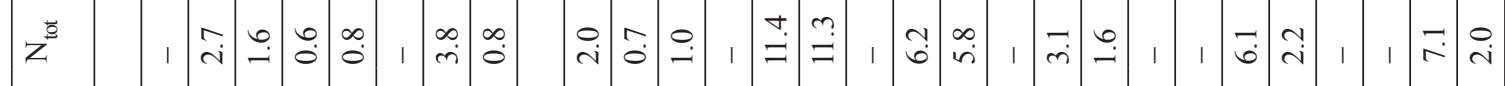

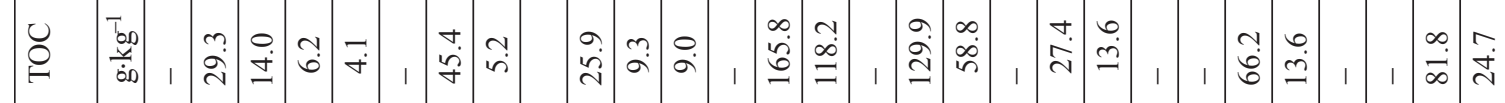

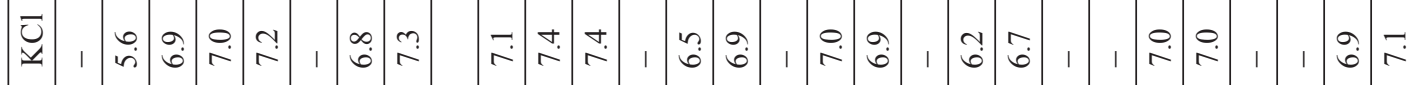

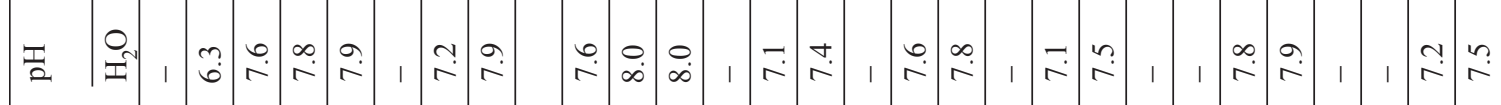
言

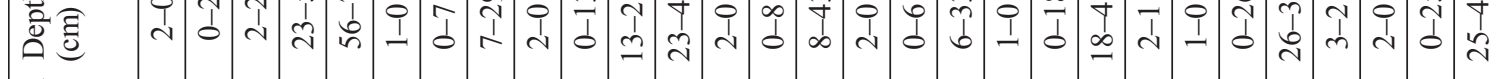
है 亏ें 尊 言

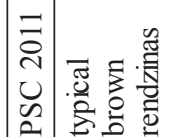
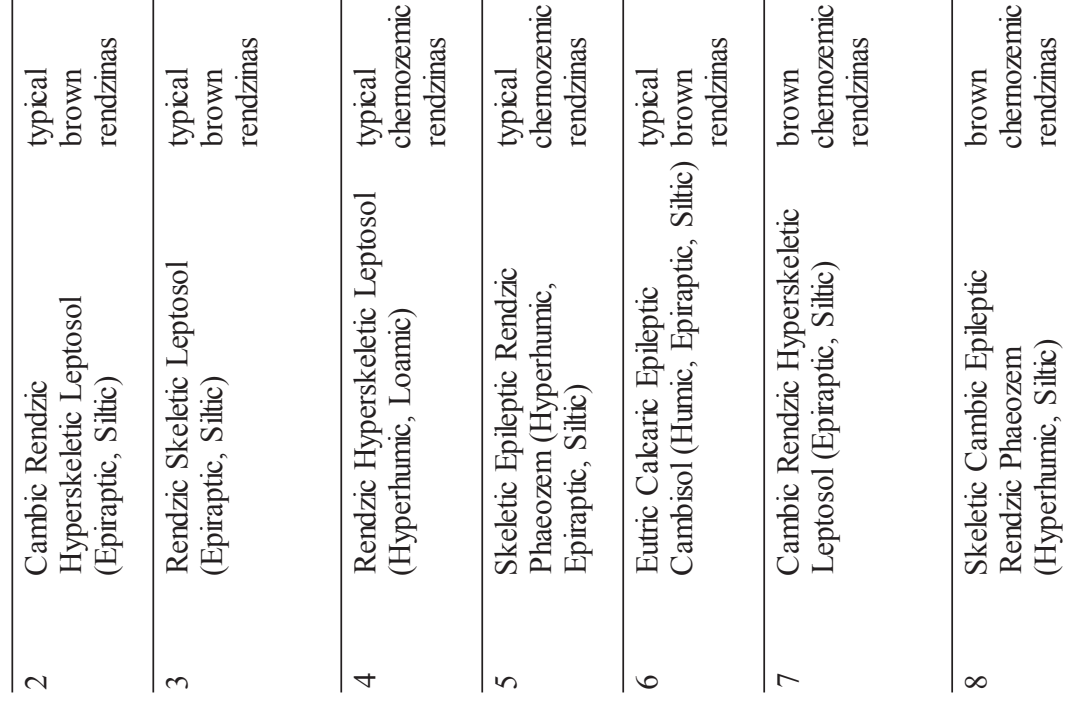


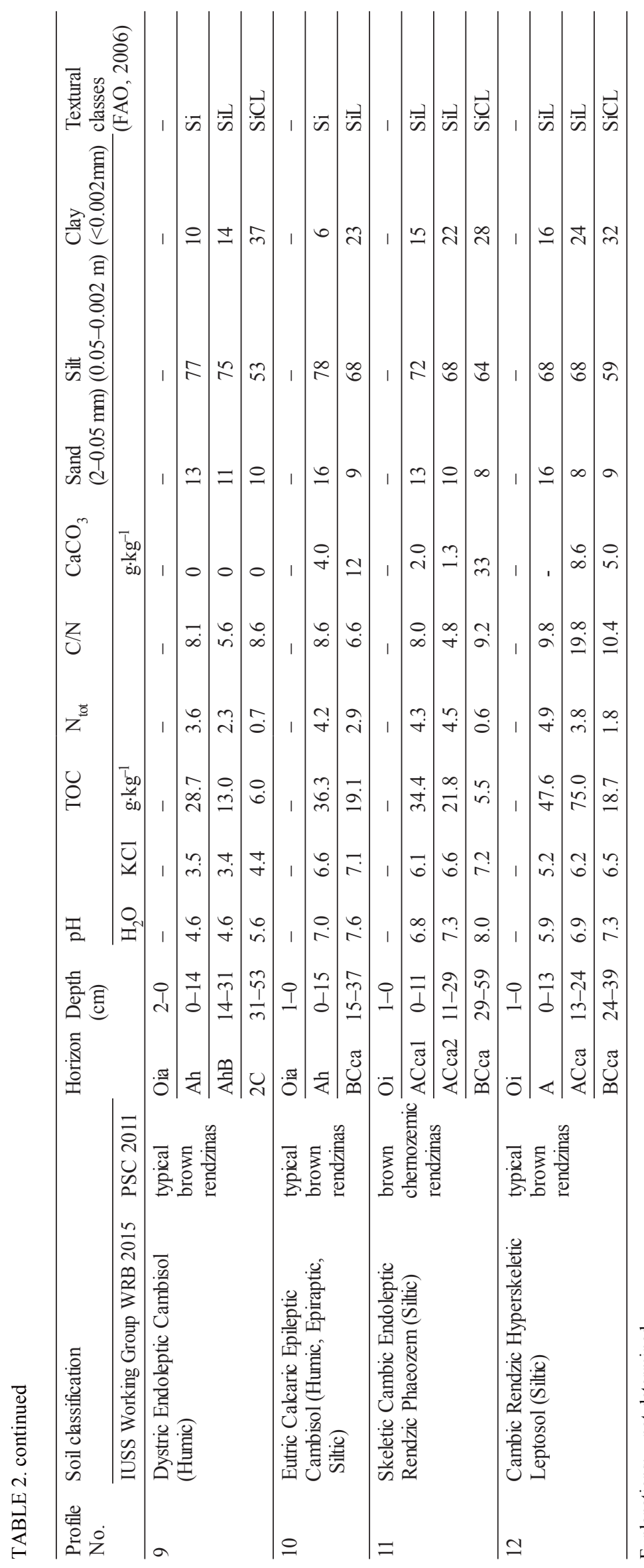

The texture of soils was varied (Fig. 4). In general, silt fraction showed the greatest share in every horizon. Within some soils (profiles 5, 6, 9, 10,11 and 12), the texture highlights vertical stratification, which may suggest a different origin of the materials that composed the topsoil and parent material (Fig. 4). The uppermost soil horizons $(\mathrm{A}, \mathrm{AB})$ were characterized by silt loam (profiles 1-3, 5, 7, 8, 11 and 12), silt (profiles 6, 9 and 10) and sandy loam (profile 4). The lowermost horizons (AB, $\mathrm{BC})$ also showed variable texture in each profile. Silt loam within the lowermost horizon was characterized for profiles $1-3,6-8$ and 10 . In profile 4, sandy loam occurred. Profile 5 was characterized by silt texture in lowermost horizon. Further silt clay loam was determined in profile 9 , 11 and 12 (Fig. 4).

In each profile, $\mathrm{pH}$ values increased with depth (Table 2). The $\mathrm{pH}$ values varied vertically within the profiles, from weakly acidic to alkaline. Within uppermost horizon $\mathrm{pH}$ ranged from 4.6 to 7.8 in $\mathrm{H}_{2} \mathrm{O}$ and from 3.5 to 7.1 in $\mathrm{KCl}$ solution. In turn, lowermost horizons were characterized by $\mathrm{pH}$ from 4.6 to 8.0 in $\mathrm{H}_{2} \mathrm{O}$ and from 3.4 to 7.4 in $\mathrm{KCl}$ solution. The TOC content in the studied soil profiles ranged from 14.0 to $165 \mathrm{~g} \cdot \mathrm{kg}^{-1}$ in $\mathrm{A}$ horizons and from 4.10 to 188 in the $\mathrm{AB} /$ BC horizons. $\mathrm{N}_{\text {tot }}$ content varied throughout the soil profiles, ranging from 1.6 to 11.4 $\mathrm{g} \cdot \mathrm{kg}^{-1}$ in uppermost horizons and from 0.60 to $11.3 \mathrm{~g} \cdot \mathrm{kg}^{-1}$ in the $\mathrm{AB} / \mathrm{BC}$ horizons. In general, TOC and $\mathrm{N}_{\text {tot }}$ decreased with depth (Table 2). In most cases the $\mathrm{CaCO}_{3}$ content increased with depth (Table 2). The exception was profiles 7 and 12, where the higher content of $\mathrm{CaCO}_{3}$ occurred within uppermost horizon. Such an arrangement may be a result of the highest content of carbonate skeleton within this horizon. $\mathrm{CaCO}_{3}$ content ranged from 0.0 to 210 and from 0.0 to $336 \mathrm{~g} \cdot \mathrm{kg}^{-1}$ in upper and lowermost horizons respectively. It was noted that $\mathrm{CaCO}_{3}$ content was the highest in profiles 3 and 8 (Table 2).

We investigated lithological discontinuity based on the LDI, UV1 and UV2 indice values. The majority of studied profiles 2, 3, 5-8 and 10 met criteria of profile lithological discontinuity. According 
TABLE 3. Lithological discontinuity values in studied soil

\begin{tabular}{|c|c|c|c|c|}
\hline Profile No. & Depth (cm) & LDI & $\mathrm{UV}_{1}$ & $\mathrm{UV}_{2}$ \\
\hline \multirow[t]{5}{*}{1} & $2-0$ & & & \\
\hline & $0-2$ & & -0.18 & -0.08 \\
\hline & $2-23$ & & -0.01 & 0.09 \\
\hline & $23-56$ & & 0.06 & 0.08 \\
\hline & $\begin{array}{l}56-78 \\
\end{array}$ & & & \\
\hline \multirow[t]{3}{*}{2} & $1-0$ & & & \\
\hline & $0-7$ & 1 & -0.23 & 0.25 \\
\hline & $7-29$ & & & \\
\hline \multirow[t]{4}{*}{3} & $2-0$ & & & \\
\hline & $\begin{array}{c}0-13 \\
\end{array}$ & 1 & -0.20 & 0.77 \\
\hline & $13-23$ & & -0.22 & -0.05 \\
\hline & $23-43$ & & & \\
\hline \multirow[t]{3}{*}{4} & $2-0$ & & & \\
\hline & $0-8$ & & 0.24 & -0.08 \\
\hline & $8-43$ & & & \\
\hline \multirow[t]{3}{*}{5} & $2-0$ & & & \\
\hline & $0-6$ & 1 & 0.43 & -0.32 \\
\hline & $6-33$ & & & \\
\hline \multirow[t]{3}{*}{6} & $1-0$ & & & \\
\hline & $0-18$ & 1 & 0.60 & -0.32 \\
\hline & $18-40$ & & & \\
\hline \multirow[t]{2}{*}{7} & $2-1$ & 1 & 0.65 & -0.61 \\
\hline & $1-0$ & & & \\
\hline
\end{tabular}

to UV1 and UV2 values, the criteria have been complied by profiles $6,7,8$ and 3,7 respectively (Table 3 ).

\section{DISCUSSION}

According to Polish Soil Classification (PSC 2011) 7 studied soils (profiles: $1,2,3,6,9,10$ and 12) were classified as typical brown rendzina subtypes. Two profiles (4 and 5) were classified to typical chernozemic rendzinas and three $(7,8$ and 11$)$ to brown chernozemic rendzinas. Based on WRB (IUSS Working Group 2015) studied soils have been classified as Cambisols (profiles 1, 6, 9 and 10), Leptosols (profiles 2, 3, 4 and 7) and as Phaeozems (profiles 5, 8,11 and 12) with varied principal and supplementary qualifiers (Table 2). Chernozemic rendzinas were counted as Phaeozems and Leptosols connected with various share of skeletic ( $>2 \mathrm{~mm}$ ) fraction (Table 2$)$.

The morphology of studied brown rendzinas profiles is relatively uniform. A humus layer was present under a rather shallow organic horizon. Within $\mathrm{O}$ and $\mathrm{A}$ horizons, a high biological activity of studied soils occurred as proved by the high composition rate of organic matter and confirmed also in other studies (Kowaliński and Licznar 1976, Mazurek et al. 2016). Humus horizon of brown rendzinas

\begin{tabular}{|c|c|c|c|c|}
\hline Profile No. & Depth $(\mathrm{cm})$ & LDI & $\mathrm{UV}_{1}$ & $\mathrm{UV}_{2}$ \\
\hline \multirow[t]{2}{*}{7} & $0-26$ & 1 & 0.65 & -0.61 \\
\hline & $26-38$ & & & \\
\hline \multirow[t]{4}{*}{8} & $3-2$ & & & \\
\hline & $1--0$ & & & \\
\hline & $0-25$ & 1 & 0.60 & -0.32 \\
\hline & $25-45$ & & & \\
\hline \multirow[t]{4}{*}{9} & $2-0$ & & & \\
\hline & $0-14$ & & -0.10 & -0.17 \\
\hline & $14-31$ & & -0.19 & -0.10 \\
\hline & $31-53$ & & & \\
\hline \multirow[t]{3}{*}{10} & $1-0$ & & & \\
\hline & $0-15$ & 1 & 0.27 & -0.48 \\
\hline & $15-37$ & & & \\
\hline \multirow[t]{4}{*}{11} & $1-0$ & & & \\
\hline & $0-11$ & & -0.01 & -0.26 \\
\hline & $11-29$ & & 0.18 & -0.22 \\
\hline & 29-59 & & & \\
\hline \multirow[t]{4}{*}{12} & $1-0$ & & & \\
\hline & $0-13$ & & 0.21 & -0.54 \\
\hline & $13-24$ & & -0.11 & 0.14 \\
\hline & 24-39 & & & \\
\hline
\end{tabular}

generally presents rather mollic character but does not meet depth criteria of this epipedon (PSC 2011). Usually, well developed humus horizons transits with the depth into cambic horizon (IUSS Working Group WRB 2015). The cambic horizon was usually characterized by much lighter color compared to humus horizon and subangular structure. The color of cambic horizons (Table 1) is debatable. According to Licznar (1976), such soil color is connected with limestones weathering into terra fusca or terra rossa.

Chernozemic rendzinas in the ONP occurred in the foothills and relative flat slope partitions. It has to be noted that this soil subtype share within the studied soils is low. In another regions, this soil type is associated with rather soft calcareous or gypsic parent material (Licznar 1976, Ciarkowska and Niemyska-Łukaszuk 2004). In opposition, Jurrasic limestones belong to recalcitrant parent material when considering rock weathering rate and development of the regolith (Lewandowski 2011). In chernozemic rendzinas, characteristic morphological traits are the humus horizon with its well-developed crumby structure, dark color and high biological activity. Soils showed morphological properties of chernozemic rendzinas that additionally showed a cambic horizon below the mollic horizon. They were classified as a brown chernozemic rendzina subtype (PSC 2011). 
In terms of lithological structure, the area of the Ojców National Park (ONP) is mostly characterized by occurrence of Jurassic limestones that comprises the parent material "base" for studied soils (Fig. 2). The limestones are usually overlaid by cover beds consisting of regolith of limestones and shallow periglacial loess mantle from the last glacial period (Vistulian) (Mazurek et al. 2010, Mazurek and Zadrożny 2011, PSC 2011, Zalewa 2001, Greszta and Bitka 1977). Depth of loess layer is the most important factor determining soil type of the ONP (Fig. 2). Soils located on high plateaus, where loess is about $2 \mathrm{~m}$ deep, are classified as clay-illuvial soils according to PSC (2011). Proper alluvial soils occur in valleys. The most common ONP slope types are dominated by rendzinas as well as shallow clay-illuvial soils. These soils were developed from shallow loess layer overlaid by limestones. Therefore, rendzinas occurrence is more frequent in central part of Park occupied chiefly by the Prądnik river valley. Where the loess layer is absent or has shallow thickness, initial rendzinas may be developed. The proportion of silt sediments to weathered limestones is not always easy to determine especially in field studies. Therefore, analysis of the particle size distribution or other properties (e.g. mineralogy of heavy minerals) is useful to assess heterogeneous character of pedons (Lorz 2008, Waroszewski et al. 2013, 2015, Kowalska et al. 2016). There are also difficulties in distinguishing pure limestone regolith from the limestone regolith covered by significant admixture of allochthonous loess in the field.

The regolith depth is considerable on slopes also due to mass movement (Schaetzl and Anderson 2005, Waroszewski et al. 2017b). Additionally, there are
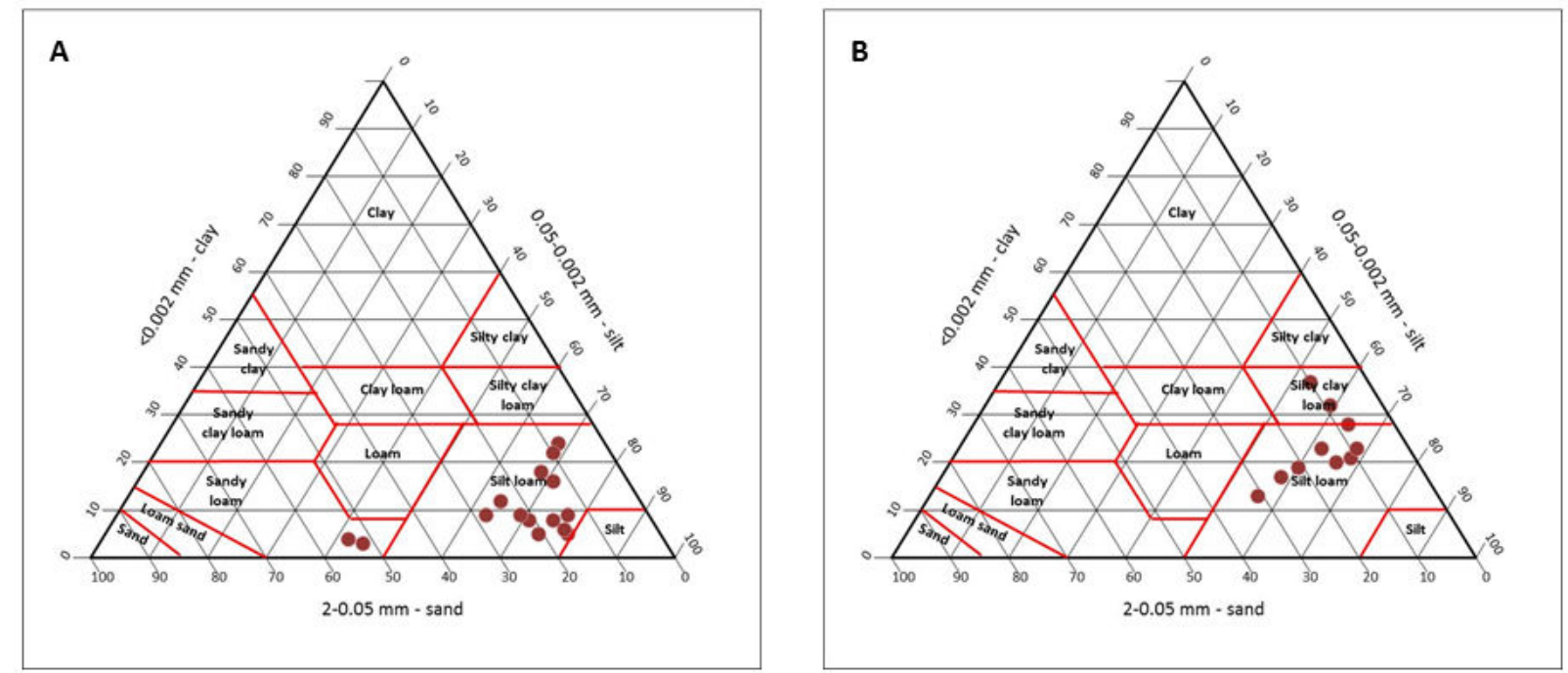

FIGURE 4. Comparison of soil texture in studied rendzinas of the Ojców National Park: A - in A horizons, B - in parent material (horizons $\mathrm{BC}$ or $\mathrm{C}$ ) 
1997). An additional finding is that humus horizons of studied soils were developed within more silty upper partition of profiles (Fig. 4). We assume that physical properties of loess layer can facilitate humus accumulation process and sequestration of carbon in soil (Grüneberg et al. 2014).

This rendzinas stratification model is consistent with earlier published papers devoted to the formation of cover beds in Pleistocene in mountain and upland areas of Central Europe (Kleber 1997, Veit et al. 2002, Semmel and Therhorst 2010). Upper loess cover is an analog to upper and middle periglacial cover beds. Regolith of limestones could be considered periglacial basal cover beds.

LDI and UV values were used in order to prove lithological discontinuity occurrence in profiles and 'mixed' character of studied rendzinas. The heterogeneous character of studied soils was confirmed in some profiles where indices of lithological discontinuity exceed limits for geologically uniform soil profiles (profiles 2, 3, 5, 6, 7, 8 and 10). Lithological discontuity was stated in 4 profiles of brown rendzinas and in 2 chernozemic rendzinas. The comparison of the lithological discontinuity methods allowed us to state that seven studied profiles met the criteria for LDI (IUSS Working Group WRB 2015) and only four profiles met the criteria for UV (Schaetzl and Anderson 2005, Kowalska et al. 2016) (Table 3). This result is compatible with the literature as pedogenesis is influenced by the thickness of loess mantle (Zalewa 2001, Waroszewski et al. 2017a). As a result, when the loess layer is deep, the clay-illuvial soils may be formed, and when loess did not affect the soils so deep, rendzinas are formed (Zalewa 2001). Nevertheless, another question concerns the 'cleanliness' of parent material. It seems to be correct that heterogeneous soils may be formed on the area of the ONP. The main parent material (Jurassic limestones) of ONP soils was conditioned by long-term changes that included mainly denudation processes or/and weathering in conditions of strong relief formation circumstances. These complex processes led to accumulation on slopes rubble-loamy cover beds in early Pleistocene as a periglacial product of limestones weathering and denudation (Krajcarz and Madeyska 2013). It should be noted that glaciation did not touch the area of the Ojców Plateau that was connected with occurrence of the form "concave nunatak", which is upland surrounded by ice sheet (Lewandowski 2011). A relative young loess sediments covered area of the OPN was accumulated in late Pleistocene. The late Pleistocene and Holocene environment affected loess sediments by slope processes and interaction with limestones regolith and cover beds (Pawelec 2001). Additionally, we can assume that in more stable parent material development stages in Pleistocene pedogenesis could have taken place and its effect was destroyed due to later denudation processes (Krajcarz and Madeyska 2013).

Hence, ONP parent material is an effect of complicated and complex geomorphological processes. The loess cover is of a different thickness than might be supposed depending on the conditions of the relief, which was additionally differentiated as a result of slope processes as found by other authors (Hasse et al. 2007, Waroszewski et al. 2017a). In a relatively small area, the shallow rendzinas and deep clay-illuvial soils formed from loess are adjacent to each other e.g. in the area of the Krakow Gate or the road to the Murownia village (Mazurek et al. 2010). It was confirmed in the earlier studies the catenal arrangement of soils is strongly related to altitude. Both uniform and mixed rendzinas occupy a lower slope position, whereas clay illuvial soils in the complexes with rendzinas occur in top plateaus (Greszta and Bitka 1977, Małek and Wężyk 1999).

It is widely recognized that rendzinas contain a great content of skeleton within the surface horizons, under which the cambic horizon occurs and subsequently parent material in form of karst Jurassic limestone (Strzemski 1950, Kuźnicki 1965). Characteristic feature of studied ONP's soils was share of coarse fractions $(>2 \mathrm{~mm})$ that in surface mineral horizons ranged from 0 to $60 \%$, whereas in deepest analyzed horizons that share amounted $50-90 \%$ (Table 1). The increasing share of limestone fragments in profile was accompanied by higher $\mathrm{pH}$ values as well as higher calcium carbonate content (Table 2). The same similarities could be found between rendzinas in the ONP and soils in the Pieniny Mts. (Zaleski et al. 2016) or the Tatry Mts. (Miechówka 2001). The specific character of surface horizons has been described, which is the result of accumulated loess and cover beds (Lorz 2008, Waroszewski et al. 2017a). Therefore, the fine earth has a strictly allochthonous character in relation to the skeleton (coarse fragments), which is the specific feature of rendzinas located in the area of the ONP. This entails relatively low values of $\mathrm{pH}$ and low amount of primary calcium carbonate, which in addition is supported by the impact of forest vegetation (Zasoński 1992, Ciarkowska 2000). It may be noted that the deeper layer of loess, the more acidic the character of studied rendzinas surface horizons, which is also directly related with the amount of calcium carbonate within the fine earths. 


\section{CONCLUSIONS}

The studied ONP rendzinas were classified as brown or chernozemic rendzinas. Despite the quite uniform morphology, in most cases the soil profiles were of heterogeneous character and even lithological discontinuities were noted. Silty character of humus horizons allows us to consider the studied soils as mixed rendzinas. Occurrence of studied rendzinas is connected with middle slope location, where regolith of Jurassic limestones is mixed with the loess layer. The slope consisted favorable conditions for mixing in-situ lithological material with allochthonous loess. This specific lithological set was characterized by more silty layers within the surface horizons compared with more clayey character of weathering base covers beds derived from Jurassic limestones. It was noted that when loess layer is deep, the clay-illuvial soils may be formed and when loess layer is moderate, rendzinas are formed. This study also showed that pure (uniform) rendzinas were formed only in more exposed forms of the terrain like inselbergs built of limestones 'rocky limestones'.

It has also been noted that the character of ONP's soils is the result of parent material heterogeneity. Jurassic limestones forming the main parent material of ONP soils were conditioned by long-term changes that included mainly denudation processes or/and weathering under conditions of strong relief. Moreover, the lithological discontinuities found in part of the studied profiles were confirmed by the LDI and UV indices used.

\section{REFERENCES}

Ahr S. W., Nordt L.C., Driese S.G., 2012. Assessing lithologic discontinuities and parent material uniformity within the Texas sandy mantle and implications for archaeological burial and preservation potential in upland settings. Quaternary Research (United States) 78(1): 60-71.

Ciarkowska K., 2000. Characteristic of brown gypsic rendzinas. Roczniki Gleboznawcze - Soil Science Annual 51(1/2): 101-111.

Ciarkowska K., Niemyska-Łukaszuk J., 2004. Microstructure and selected properties of gypsic chermozemic rendzinas occurring on the Niecka Nidziańska area and Vallada Agordina valley (Italian Dolomites). Roczniki Gleboznawcze - Soil Science Annual 55(4): 15-22.

Dobrzański B., Turski R., 1964. An attempt of determining rendzinas genesis on the occurrence of heavy minerals. Roczniki Gleboznawcze - Soil Science Annual 14(supl.): 295-301.

FAO, 2006. Guidelines for soil description. fourth ed. Rome: 77 pp.

Gradziński M., 2001. Inanimate nature of Ojców National Park - the existing research problems, threats, conservation problems. Prądnik. Prace Muz. Szafera 17: 33-42.

Greszta J., Bitka R., 1977. Gleby. [In:] Przyroda Ojcowskiego Parku Narodowego. Studia Naturae ser. B, 28: 81-89.
Grüneberg E., Ziche D., Wellbrock N., 2014. Organic carbon stocks and sequestration rates of forest soils in Germany. Global Change Biology 20(8): 2644-2662.

Haase D., Fink J., Haase G., Ruske R., Pécsi M., Richter H., Altermann M., Jager K.D., 2007. Loess in Europe - its spatial distribution based on a European Loess Map, scale 1:2,500,000. Quaternary Science Reviews 26: 1301-1312.

IUSS Working Group WRB, 2015. World Reference Base for Soil Resources 2014, update 2015. International soil classification system for naming soils and creating legends for soil maps. World Soil Resources Reports No. 106. FAO, Rome: 182.

Kleber A., 1997. Cover-beds as soil parent materials in midlatitude regions. Catena 30(2-3): 197-213.

Kowaliński S., Licznar S., 1976. Micromorphological properties of rendzinas developed from limestones of different geological formations. Roczniki Gleboznawcze - Soil Science Annual 27(2): 93-97.

Kowalska J., Mazurek R., Gąsiorek M., Setlak M., Zaleski T., Waroszewski, J., 2016. Soil pollution indices conditioned by medieval metallurgical activity - A case study from Krakow (Poland). Environmental Pollution, 218: 1023-1036.

Kowalska J., Kajdas B., Zaleski T., 2017. Variability of morphological, physical and chemical properties of soils derived from carbonate-rich parent material in the Pieniny Mountains (south Poland), Soil Science Annual 68(1): 27-38.

Krajcarz M.T., Madeyska T., 2013. New profile of Ciemna Cave sediments (Polish Jura) - problem of correlation with former investigations. [In:] (Filippi M., Bosák P., Editors), Proceedings of the 16th International Congress of Speleology, July 21-28, Brno, 1. Czech Speleological Society. Praha: 146-149.

Kuźnicki F., 1965. Properties and typology of soils from cretaceous decalcified siliceous rock of Roztocze region in relation to characteristics and genetic division of rendzinas. Roczniki Gleboznawcze - Soil Science Annual 15(2): 345-408.

Kuźnicki F., Skłodowski P., 1973. Content of various forms of humus compounds in rendzina soils as compared with other soil types. Roczniki Gleboznawcze - Soil Science Annual 24(2): 187-202.

Kuźnicki F., Skłodowski P., 1976. Content and characteristics of the forms of humus compounds in rendzinas developed from carbonate rocks of different geological age. Roczniki Gleboznawcze - Soil Science Annual 27(2): 127-136.

Lewandowski J., 2011. „Glacial oasis” in the Cracow-Częstochowa Upland - results of studies during the last fifty years. Przegląd Geologiczny 59: 732-738.

Licznar S.E., 1976. Rendzinas and soils on limestone of the Opole region in the light of micromorphological and physicochemical investigations. Roczniki Gleboznawcze - Soil Science Annual 27(3): 73-121.

Licznar S.E., Drozd J., Licznar M., 1997. Studies of some relict weathered limestone Jurassic using submicromorphological methods. Roczniki Gleboznawcze - Soil Science Annual 48(1-2: 71-77.

Ligęza S., 2009. Determination of lithological discontinuities within the soils. Roczniki Gleboznawcze - Soil Science Annual 60(1): 77-84.

Lityński T., Jurkowska H., Gorlach E., 1976. Chemical-Agricultural Analysis. PWN Warszawa: 332 pp.

Lorz C., 2008. Lithological Discontinuous Soils - Archives for the Pedo-Geochemical Genesis of the Soil-Regolith-Complex? Zeitschrif für Geomorphologie 52: 119-132. 
Lorz, C., Frühauf, M., Mailänder, R., Phillips, J.D., 2010. Lithologic discontinuities in cover beds influencing soil evolution and soil properties. Geophysical Research Abstracts 12: 63-68.

Lorz C., Phillips J., 2006. Pedo-Ecological Consequences of Lithological discontinuities in soils. Examples from Central Europe. Journal of Plant Nutrition and Soil Science 169: 573-581.

Lorz C., Frühauf M., Mailänder R., Phillips J.D., Kleber A., 2013. Influence of Cover Beds on Soils. [In:] (Kleber A., Terhorst B. Editors), Mid-Latitude Slope Deposits (Cover Beds), Elsevier: 95-125.

Małek S., Wężyk P., 1999. The amount of element reached upper soil layer in beech stands in the Ojców National Park in 1997 and 1998. Ochrona Środowiska i Zasobów Naturalnych 18: 347-355.

Mazurek R., Wieczorek J. Zadrożny P., 2010. Mercury content in soils of the Ojców National Park. Ecological Chemistry And Engineering 17(4-5): 439-447.

Mazurek R., Zadrożny P., 2011. Cadmium in Soils of the Ojców National Park. Ecological Chemistry and Engineering 18(5-6): 771-776.

Mazurek R., Zadrożny P., 2013. Sulphur in the forest soils of the Ojców National Park. Ecological Chemistry and Engineering A, 20, 11: 1327-1333.

Mazurek R., Kowalska J., Gasiorek M., Setlak M., 2016. Micromorphological and physico-chemical analyses of cultural layers in the urban soil of a medieval city - a case study from Krakow, Poland. Catena 141: 73-84.

Medwecka-Kornaś A., Kornaś J., 1963. Vegetation map of Ojców National Park Nature Protection 26: 17-87.

Miechówka A., 2001. Content of different forms of iron in rendzinas situated above the upper tree limit in the Tatra Mts. Roczniki Gleboznawcze - Soil Science Annual 52(supl.): 135-143.

Miechówka A., 2002. Selected properties of rendzinas occurring under dwarf pine in the Tatra National Park. Roczniki Gleboznawcze - Soil Science Annual 53(1/2): 5-12.

Oyama M., Takehara H., 1970. Revised Standard Soil Color Charts. Research Council for Agriculture, Forestry and Fisheries, Japan.

Pawelec H., 2001. Lithogenetic classification of periglacial slope covers in the southern part of the Ojców Plateau (southern Poland). Przegląd Geologiczny 52: 990-996.

Pranagal J., 2004. Differential porosity of rendzina and water stability of its aggregates in various cultivation system. Roczniki Gleboznawcze - Soil Science Annual 55(2): 339-347.

Polish Standard, 1998. Soil and mineral soil materials - sampling and determination of particle size distribution. PN-R-04032. Polish Committee for Standardization, Warszawa.
Polish Soil Classification (Systematyka gleb Polski), 1989. Roczniki Gleboznawcze - Soil Science Annual 50(3/4): 1-151.

Polish Soil Classification (Systematyka gleb Polski), 2011. Roczniki Gleboznawcze - Soil Science Annual 62(3): 1-193.

Schaetzl R., Anderson S., 2005. Soils, Genesis and Geomorphology. Cambridge University Press. Cambridge: $832 \mathrm{pp}$.

Schejbal-Chwastek M., Marszalek M., 1999. Mineralogical and chemical impact of anthropogenic emissions on soils and rocks of the Ojców National Park (Poland). Geologica Carpathica 50(5): 409-412.

Semmel A., Terhorst B., 2010. The concept of the Pleistocene periglacial cover beds in central Europe: A review. Quaternary International 222(1): 120-128.

Strzemski M., 1950. The rendzinas formed on the Triassic Limestones near Piekoszów. Roczniki Gleboznawcze-Soil Science Annual 1: 99-103.

Veit H., Mailänder R., Vonlanthen C., 2002. Periglaziale Deckschichten im Alpenraum: Bodenkundliche und landschaftsgeschichtliche Bedeutung. Petermanns Geographische Mitteilungen 146(4): 6-14.

Waroszewski J., Kalinski K., Malkiewicz M., Mazurek R., Kozlowski G., Kabala C., 2013. Pleistocene-Holocene coverbeds on granite regolith as parent material for Podzols - An example from the Sudeten Mountains. Catena 104: 161-173.

Waroszewski J., Malkiewicz M., Mazurek R., Labaz B., Jezierski P., Kabala C., 2015. Lithological discontinuities in Podzols developed from sandstone cover beds in the Stołowe Mountains (Poland). Catena 126: 11-19.

Waroszewski J., Sprafke T., Kabała C., Musztyfaga E., Łabaz B., Woźniczka P., 2017a. Aeolian silt contribution to soils on mountain slopes (Mt. Ślęża, southwest Poland). Quaternary Research: 1-16.

Waroszewski J., Egli M., Brandová D., Christl M., Kabała C., Malkiewicz M., Kierczak J., Glina B. and Jezierski P., 2017b. Identifying slope processes over time and their imprint in soils of medium-high mountains of Central Europe (the Karkonosze Mountains, Poland). Earth Surface Processes and Landforms 43: 1195-1212.

Zagórski Z., 2001. Micromorphological characteristics of carbonates in rendzina soils developed from cretaceous marls. Roczniki Gleboznawcze - Soil Science Annual 52(1/2): 79-88.

Zaleski T., Mazurek R., Gąsiorek M., Wanic T., Zadrożny P., Józefowska A., Kajdas Bartłomiej, 2016. Soils of the forest monitoring areas in the Pieniny National Park. Pieniny - Przyroda i Człowiek 14: 3-15.

Zalewa S., 2001. Charakterystyka podtypów i rodzajów gleb Ojcowskiego Parku Narodowego. [In:] (Partyka J., Editor) Badania naukowe w południowej części Wyżyny KrakowskoCzęstochowskiej, Materiały konferencyjne, Ojców: 142-147.

Zasoński S., 1992. Krosno layers as a parent rock of flysh pararendzinas (exemplified by soils of Rymanów uplands). Roczniki Gleboznawcze - Soil Science Annual 43(3/4): 77-90.

Received: April 16, 2018

Accepted: September 27, 2018

Associated editor: t. Uzarowicz 


\section{Zróżnicowanie rędzin w Ojcowskim Parku Narodowym jako efekt czynnika litologicznego}

Streszczenie: Celem przeprowadzonych badań była ocena zróżnicowania rędzin na terenie Ojcowskiego Parku Narodowego (OPN). W badanych glebach została oceniona współzależność pomiędzy reliefem a pozycją na stoku oraz występowaniem nieciagłości litologicznej. Zgodnie z Systematyką Gleb Polski (2011) badane gleby zostały zaklasyfikowane do typu rędzin brunatnych i rędzin czarnoziemnych (typowych i z poziomem cambic). Rędziny na terenie OPN występują głównie w środkowej części stoku, gdzie regolit wapieni jurajskich jest w różnym stopniu wymieszany z naniesionym lessem. Taki układ prowadzi do formowania się pionowej heterogeniczności pod względem uziarnienia i tym samym pozwala na identyfikację nieciągłości litologicznej w obrębie profilu glebowego. Występowanie nieciągłości litologicznej w niektórych profilach badanych gleb zostało potwierdzone dzięki zastosowaniu wskaźników, takich jak: LDI i UV. Poziomy powierzchniowe charakteryzowały się mniejszym udziałem frakcji ilastej w porównaniu do głębszych części profili. Ma to związek z wpływem domieszki lessu w stropowych częściach profilów na właściwości badanych rędzin. Rędziny inicjalne (czyste) zostały wykształcone jedynie z wapieni zalegających zwykle w wyższej części stoków, podlegających zjawiskom krasowych i wykształconych często w postaci izolowanych ostańców.

Słowa kluczowe: rędziny, gleby węglanowe, Ojcowski Park Narodowy, nieciagłość litologiczna 